\title{
Unprecedented Hemiketal Cembranolides with Anti-inflammatory Activity from the Soft Coral Lobophytum durum
}

\author{
Shi-Yie Cheng, ${ }^{\dagger}$ Zhi-Hong Wen, ${ }^{\dagger} \S$ Shang-Kwei Wang, ${ }^{\ddagger}$ Shu-Fen Chiou, ${ }^{\dagger}$ Chi-Hsin Hsu, ${ }^{\dagger}{ }^{\S}$ Chang-Feng Dai, ${ }^{\perp}$ \\ Michael Y. Chiang," and Chang-Yih Duh*, ${ }^{*, \S}$ \\ Department of Marine Biotechnology and Resources, National Sun Yat-sen University, Kaohsiung 804, Taiwan, Republic of China, Department \\ of Microbiology, Kaohsiung Medical University, Kaohsiung, Taiwan, Republic of China, Institute of Oceanography, National Taiwan \\ University, Taipei, Taiwan, Republic of China, Department of Chemistry, National Sun Yat-sen University, Kaohsiung, Taiwan, Republic of \\ China, and Center of Asia-Pacific Marine Research, National Sun Yat-sen University, Kaohsiung, Taiwan, Republic of China
}

Received October 27, 2008

Chemical investigations of the soft coral Lobophytum durum have led to the isolation of three unprecedented hemiketal cembranolides, durumhemiketalolides A-C (1-3). Full NMR spectroscopic assignments are provided for all isolated metabolites. The anti-inflammatory activities of $\mathbf{1}-\mathbf{3}$ were evaluated in vitro.

Soft corals of the genus Lobophytum (Alcyoniidae) have proven to be a rich source of macrocyclic cembrane-type diterpenoids and their cyclized derivatives. ${ }^{1-8}$ Previous bioassay results of some cembranoid analogues have been shown to exhibit significant cytotoxic properties. $^{2-6}$ The continuing search for bioactive constituents prompted us to investigate the secondary metabolites of the soft coral Lobophytum durum (Tixier-Durivault, 1956). ${ }^{9}$ Our further chemical examination of this soft coral has led to the isolation of three new cembranolides, durumhemiketalolides $\mathrm{A}-\mathrm{C}$ (1-3), characterized as possessing a hemiketal tetrahydropyran ring and an $\alpha$-methylene- $\delta$-lactone $c i s$-fused to a 14 -membered ring, from the acetone-soluble extract of the organism. The details of isolation and structural elucidation of these isolated metabolites are discussed. Moreover, metabolites 1-3 were evaluated for antiinflammatory activity using RAW 264.7 macrophages, anti-HCMV (human cytomegalovirus) endonuclease activity, and antibacterial activity against Salmonella enteritidis (ATCC13076).
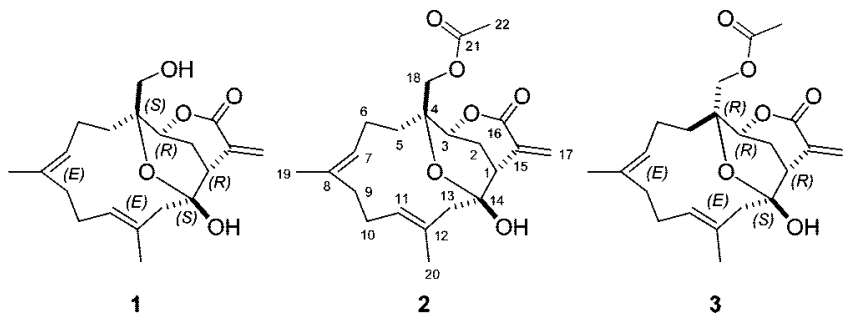

Specimens of $L$. durum were processed as has been previously reported ${ }^{9}$ to provide three new cembranolides, designated durumhemiketalolides A-C (1-3). Durumhemiketalolide A (1) was isolated as a colorless oil. The positive HRESIMS of $\mathbf{1}$ exhibited a pseudomolecular ion peak at $\mathrm{m} / z 371.1835[\mathrm{M}+\mathrm{Na}]^{+}$, consistent with the molecular formula $\mathrm{C}_{20} \mathrm{H}_{28} \mathrm{O}_{5}$, implying seven degrees of unsaturation. Its IR spectrum absorptions at 3435 and $1716 \mathrm{~cm}^{-1}$ indicated the presence of hydroxyl substituents and an $\alpha$-methylene$\delta$-lactone moiety. This assumption was supported by the ${ }^{1} \mathrm{H}$ and ${ }^{13} \mathrm{C}$ NMR signals resonating at $\delta_{\mathrm{H}} 6.32(1 \mathrm{H}, \mathrm{d}, J=1.5 \mathrm{~Hz}, \mathrm{H}-17 \mathrm{a})$, $\delta_{\mathrm{H}} 5.72(1 \mathrm{H}, \mathrm{d}, J=1.5 \mathrm{~Hz}, \mathrm{H}-17 \mathrm{~b}), \delta_{\mathrm{C}} 167.7$ (qC, C-16), 139.4

* To whom correspondence should be addressed. Tel: 886-7-5252000, ext. 5036. Fax: 886-7-5255020. E-mail: yihduh@ nsysu.edu.tw.

Department of Marine Biotechnology and Resources, National Sun Yatsen University.

${ }^{\S}$ Center of Asia-Pacific Marine Research.

₹Department of Microbiology, Kaohsiung Medical University.

${ }^{\perp}$ Institute of Oceanography, National Taiwan University.

" Department of Chemistry, National Sun Yat-sen University.
Table 1. ${ }^{1} \mathrm{H}$ NMR Spectroscopic Data (500 MHz) of Metabolites $\mathbf{1}-\mathbf{3}^{a}$ in $\mathrm{CDCl}_{3}$

\begin{tabular}{|c|c|c|c|}
\hline $\mathrm{H \#}$ & 1 & 2 & 3 \\
\hline 1 & $3.46, \mathrm{t}(9.0)^{b}$ & $3.43, \mathrm{t}(9.0)^{b}$ & $3.37, \mathrm{dd}(9.5,2.0)^{b}$ \\
\hline \multirow[t]{2}{*}{2} & a $2.36, \mathrm{~m}$ & 2.38 , ddd $(14.0,9.0,6.5)$ & $2.30, \mathrm{~m}$ \\
\hline & b $2.03, \mathrm{~m}$ & 2.00, ddd $(14.0,10.0,9.0)$ & $1.89, \operatorname{ddd}(13.0,5.5,2.0)$ \\
\hline 3 & $4.70, \mathrm{dd}(10.5,6.0)$ & $4.48, \mathrm{dd}(10.0,6.5)$ & $4.16, \mathrm{dd}(11.0,5.5)$ \\
\hline \multirow[t]{2}{*}{5} & a 1.74 , dd $(9.5,4.0)$ & $1.75, \mathrm{~m}$ & $2.27, \mathrm{~m}$ \\
\hline & b $1.64, \mathrm{~m}$ & $1.66, \mathrm{~m}$ & $1.71, \mathrm{~m}$ \\
\hline \multirow[t]{2}{*}{6} & a $2.14, \mathrm{~m}$ & $2.23, \mathrm{~m}$ & $2.14, \mathrm{~m}$ \\
\hline & b $2.14, \mathrm{~m}$ & $2.08, \mathrm{~m}$ & $2.08, \mathrm{~m}$ \\
\hline 7 & $5.09, \mathrm{t}(7.5)$ & $5.14, \mathrm{t}(7.0)$ & $5.09, \mathrm{t}(6.0)$ \\
\hline \multirow[t]{2}{*}{9} & a $2.18, \mathrm{~m}$ & $2.17, \mathrm{~m}$ & $2.16, \mathrm{~m}$ \\
\hline & b $2.10, \mathrm{~m}$ & $2.11, \mathrm{~m}$ & $2.10, \mathrm{~m}$ \\
\hline \multirow[t]{2}{*}{10} & a $2.35, \mathrm{~m}$ & $2.27, \mathrm{~m}$ & $2.35, \mathrm{~m}$ \\
\hline & b $2.16, \mathrm{~m}$ & $2.18, \mathrm{~m}$ & $2.22, \mathrm{~m}$ \\
\hline 11 & $5.35, \mathrm{t}(7.5)$ & $5.32, \mathrm{t}(6.5)$ & 5.10, brt $(6.0)$ \\
\hline \multirow[t]{2}{*}{13} & a $2.77, \mathrm{~d}(13.5)$ & $2.79, \mathrm{~d}(14.0)$ & $2.61, \mathrm{~d}(13.5)$ \\
\hline & b $2.30, \mathrm{~d}(13.5)$ & $2.23, \mathrm{~d}(14.0)$ & $2.38, \mathrm{~d}(13.5)$ \\
\hline \multirow[t]{2}{*}{17} & a $6.32, \mathrm{~d}(1.5)$ & $6.30, \mathrm{~d}(2.0)$ & $6.35, \mathrm{~d}(2.0)$ \\
\hline & b $5.72, \mathrm{~d}(1.5)$ & $5.70, \mathrm{~d}(2.0)$ & $5.72, \mathrm{~d}(2.0)$ \\
\hline \multirow[t]{2}{*}{18} & a $3.76, \mathrm{~d}(11.0)$ & $4.34, \mathrm{~d}(12.0)$ & $4.15, \mathrm{~d}(11.5)$ \\
\hline & b $3.47, \mathrm{~d}(11.0)$ & $4.00, \mathrm{~d}(12.0)$ & $4.09, \mathrm{~d}(11.5)$ \\
\hline 19 & $1.66, \mathrm{~s}$ & $1.63, \mathrm{~s}$ & $1.52, \mathrm{~s}$ \\
\hline 20 & $1.75, \mathrm{~s}$ & $1.73, \mathrm{~s}$ & $1.77, \mathrm{~s}$ \\
\hline 22 & & $2.09, \mathrm{~s}$ & $2.13, \mathrm{~s}$ \\
\hline
\end{tabular}

${ }^{a}$ Assigned by COSY, HSQC, NOESY, and HMBC experiments. ${ }^{b} J$ values (in $\mathrm{Hz}$ ) are in parentheses.

(qC, C-15), and $\delta_{\mathrm{C}} 124.0\left(\mathrm{CH}_{2}, \mathrm{C}-17\right)$. The ${ }^{1} \mathrm{H}$ and ${ }^{13} \mathrm{C}$ NMR spectra (Tables 1 and 2) of $\mathbf{1}$ contained resonances for two trisubstituted double bonds at C-7/C-8 $\left[\delta_{\mathrm{H}} 5.09(\mathrm{t}, J=7.5 \mathrm{~Hz}, 1 \mathrm{H}) ; \delta_{\mathrm{C}} 133.8\right.$ $(\mathrm{qC})$ and $127.4(\mathrm{CH})]$ and $\mathrm{C}-11 / \mathrm{C}-12\left[\delta_{\mathrm{H}} 5.35(\mathrm{t}, J=7.5 \mathrm{~Hz}, 1 \mathrm{H})\right.$; $\delta_{\mathrm{C}} 128.4(\mathrm{qC})$ and $\left.131.0(\mathrm{CH})\right]$. Meanwhile, the HMBC correlations (Figure 1) observed from $\mathrm{H}_{3}-19$ to $\mathrm{C}-7, \mathrm{C}-8$, and $\mathrm{C}-9 ; \mathrm{H}_{3}-20$ to $\mathrm{C}-11, \mathrm{C}-12$, and $\mathrm{C}-13$, led to the position of the two double bonds. From the COSY spectrum of $\mathbf{1}$ (Figure 1), it was possible to establish the proton sequence connecting $\mathrm{H}-1$ to $\mathrm{H}-3, \mathrm{H}_{2}-5$ to $\mathrm{H}-7$, and $\mathrm{H}_{2}-9$ to $\mathrm{H}-11$. The ${ }^{1} \mathrm{H}-{ }^{1} \mathrm{H}$ COSY correlations further observed between $\mathrm{H}-1$ and $\mathrm{H}_{2}-17, \mathrm{H}_{3}-19$ and $\mathrm{H}-7$, and $\mathrm{H}_{3}-20$ and $\mathrm{H}-11$ showed the allylic coupling of the above protons. The connectivity from $\mathrm{C}-3$ to $\mathrm{C}-5$ was confirmed by the HMBC correlations from $\mathrm{H}_{2}-18$ to $\mathrm{C}-3, \mathrm{C}-4$, and $\mathrm{C}-5$ and from $\mathrm{H}_{2}-5$ to $\mathrm{C}-3$ and $\mathrm{C}-4$. The connectivity from $\mathrm{C}-13$ to $\mathrm{C}-1$ was confirmed by the $\mathrm{HMBC}$ correlations from $\mathrm{H}_{2}-13$ to $\mathrm{C}-14$ and $\mathrm{C}-1$. The $\mathrm{HMBC}$ spectrum showed correlations from $\mathrm{H}_{3}-19$ to $\mathrm{C}-7, \mathrm{C}-8$, and $\mathrm{C}-9 ; \mathrm{H}_{3}-20$ to $\mathrm{C}-11, \mathrm{C}-12$, and $\mathrm{C}-13$, proving the direct attachment between $\mathrm{C}-8$ and $\mathrm{C}-9$, and $\mathrm{C}-12$ and $\mathrm{C}-13$. In addition, the fusion of the $\alpha$-methylene- $\delta$-lactone moiety was confirmed by analysis of the $\mathrm{HMBC}$ correlation from $\mathrm{H}-3$ to $\mathrm{C}-16$. Another characteristic feature of the ${ }^{13} \mathrm{C}$ NMR spectrum of $\mathbf{1}$ was the presence of a quaternary 
Table 2. ${ }^{13} \mathrm{C}$ NMR Spectroscopic Data of Metabolites $\mathbf{1}-\mathbf{3}^{a}$

\begin{tabular}{|c|c|c|c|}
\hline C\# & 1 & 2 & 3 \\
\hline 1 & $45.9, \mathrm{CH}^{b}$ & $46.0, \mathrm{CH}^{b}$ & $47.7, \mathrm{CH}^{b}$ \\
\hline 2 & $32.4, \mathrm{CH}_{2}$ & $32.6, \mathrm{CH}_{2}$ & $35.3, \mathrm{CH}_{2}$ \\
\hline 3 & 85.2, $\quad \mathrm{CH}$ & $82.6, \mathrm{CH}$ & $82.6, \mathrm{CH}$ \\
\hline 4 & $72.2, \mathrm{qC}$ & 73.7, qC & $73.9, \mathrm{qC}$ \\
\hline 5 & $34.3, \mathrm{CH}_{2}$ & $33.6, \mathrm{CH}_{2}$ & $34.9, \mathrm{CH}_{2}$ \\
\hline 6 & $22.1, \mathrm{CH}_{2}$ & $21.8, \mathrm{CH}_{2}$ & $22.4, \mathrm{CH}_{2}$ \\
\hline 7 & $127.4, \mathrm{CH}$ & $127.8, \mathrm{CH}$ & $126.4, \mathrm{CH}$ \\
\hline 8 & $133.8, \mathrm{qC}$ & $133.4, \mathrm{qC}$ & $133.7, \mathrm{qC}$ \\
\hline 9 & $39.5, \mathrm{CH}_{2}$ & $39.3, \mathrm{CH}_{2}$ & $38.3, \mathrm{CH}_{2}$ \\
\hline 10 & $25.4, \mathrm{CH}_{2}$ & $25.1, \mathrm{CH}_{2}$ & $25.2, \mathrm{CH}_{2}$ \\
\hline 11 & $131.0, \mathrm{CH}$ & $131.4, \mathrm{CH}$ & $130.8, \mathrm{CH}$ \\
\hline 12 & $128.4, \mathrm{qC}$ & $127.7, \mathrm{qC}$ & $128.0, \mathrm{qC}$ \\
\hline 13 & $46.2, \mathrm{CH}_{2}$ & $45.9, \mathrm{CH}_{2}$ & $47.4, \mathrm{CH}_{2}$ \\
\hline 14 & 114.0, qC & $114.7, \mathrm{qC}$ & $115.3, \mathrm{qC}$ \\
\hline 15 & $139.4, \mathrm{qC}$ & 139.6, qC & 139.3, qC \\
\hline 16 & 167.7, qC & $167.7, \mathrm{qC}$ & $170.8, \mathrm{qC}$ \\
\hline 17 & $124.0, \mathrm{CH}_{2}$ & $123.5, \mathrm{CH}_{2}$ & $124.2, \mathrm{CH}_{2}$ \\
\hline 18 & $66.7, \mathrm{CH}_{2}$ & $67.3, \mathrm{CH}_{2}$ & $66.9, \mathrm{CH}_{2}$ \\
\hline 19 & $15.3, \mathrm{CH}_{3}$ & $15.3, \mathrm{CH}_{3}$ & $15.6, \mathrm{CH}_{3}$ \\
\hline 20 & $19.2, \mathrm{CH}_{3}$ & $19.1, \mathrm{CH}_{3}$ & $18.0, \mathrm{CH}_{3}$ \\
\hline 21 & & 171.7, qC & $171.2, \mathrm{qC}$ \\
\hline 22 & & $20.9, \mathrm{CH}_{3}$ & $20.9, \mathrm{CH}_{3}$ \\
\hline
\end{tabular}

${ }^{a}$ Spectra recorded at $125 \mathrm{MHz}$ in $\mathrm{CDCl}_{3} .{ }^{b}$ Multiplicities are deduced by HSQC and DEPT experiments.

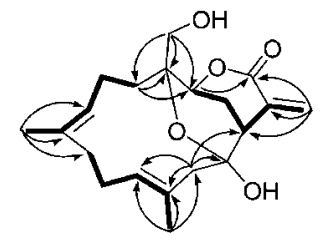

Figure 1. Selective ${ }^{1} \mathrm{H}-{ }^{1} \mathrm{H} \operatorname{COSY}(-)$ and $\operatorname{HMBC}(\rightarrow)$ correlations of 1.

nonolefinic carbon resonating at $\delta_{\mathrm{C}} 114.0$, suggesting a hemiketal functionality at C-14. In order to satisfy the seven degrees of unsaturation indicated by the molecular formula, it was apparent that the ether linkage at C-4 was involved in the highly deshielded C-14 hemiketal carbon. Therefore, the planar framework of $\mathbf{1}$, possessing a $c i s$-fused $\alpha$-methylene- $\delta$-lactone ring with a hemiketal tetrahydropyran functionality, was established unambiguously.

A computer-modeled 3D structure (Figure 2) of 1 was generated by using MM2 force field calculations for energy minimization with the molecular modeling program Chem3D Ultra 9.0. The relative configuration of $\mathbf{1}$ assigned by NOESY spectrum was compatible with those of $\mathbf{1}$ offered by computer modeling, in which the close contacts of atoms calculated in space were consistent with the NOESY correlations. The geometry of the trisubstituted olefins was assigned as $E$ based on the $\gamma$-effect of the olefinic methyl signals for C-19 and C-20 (less than 20 ppm) ${ }^{10}$ and the NOESY correlations between $\mathrm{H}-7$ and $\mathrm{H}_{2}-9, \mathrm{H}_{2}-6$ and $\mathrm{H}_{3}-19, \mathrm{H}-11$ and $\mathrm{H}_{2}-$ 13 , and $\mathrm{H}_{2}-10$ and $\mathrm{H}_{3}-20$. The relative configurations of the four chiral centers at C-1, C-3, C-4, and C-14 in 1 were elucidated by the following NOE analysis. NOE correlations between $\mathrm{H}-3$ and $\mathrm{H}_{2}-18$; $\mathrm{H}-3$ and $\mathrm{H}_{2}-2 ; \mathrm{H}-1$ and $\mathrm{H}_{2}-2 ; \mathrm{H}-1$ and $\mathrm{H}-13$ b; and $\mathrm{H}-11$ and $\mathrm{H}-13 \mathrm{a}$ indicated the $1 R^{*}, 3 R^{*}, 4 S^{*}$, and $14 S^{*}$ configurations, ${ }^{11-14}$ as depicted in Figure 2. On the basis of the above observations and other detailed NOESY correlations (Figure 2), metabolite 1 was unequivocally elucidated as $\left(1 R^{*}, 3 R^{*}, 4 S^{*}, 14 S^{*}, 7 E, 11 E\right)-14,18$ dihydroxy-4,14-epoxycembra-7,11,15(17)-trien-16,3-olide.

Durumhemiketalolide B (2) appeared as a colorless oil and exhibited a pseudo molecular ion peak at $m / z, 413.1943[\mathrm{M}+\mathrm{Na}]^{+}$ by HRESIMS, appropriate for a molecular formula of $\mathrm{C}_{22} \mathrm{H}_{30} \mathrm{O}_{6}$. The IR spectrum also revealed the presence of ester $\left(1744 \mathrm{~cm}^{-1}\right)$, $\alpha$-methylene- $\delta$-lactone $\left(1721 \mathrm{~cm}^{-1}\right)$, and hydroxy $\left(3453 \mathrm{~cm}^{-1}\right)$ moieties. The NMR spectroscopic data were found to be very similar to those of $\mathbf{1}$ (Tables 1 and 2), except that the 18-hydroxy

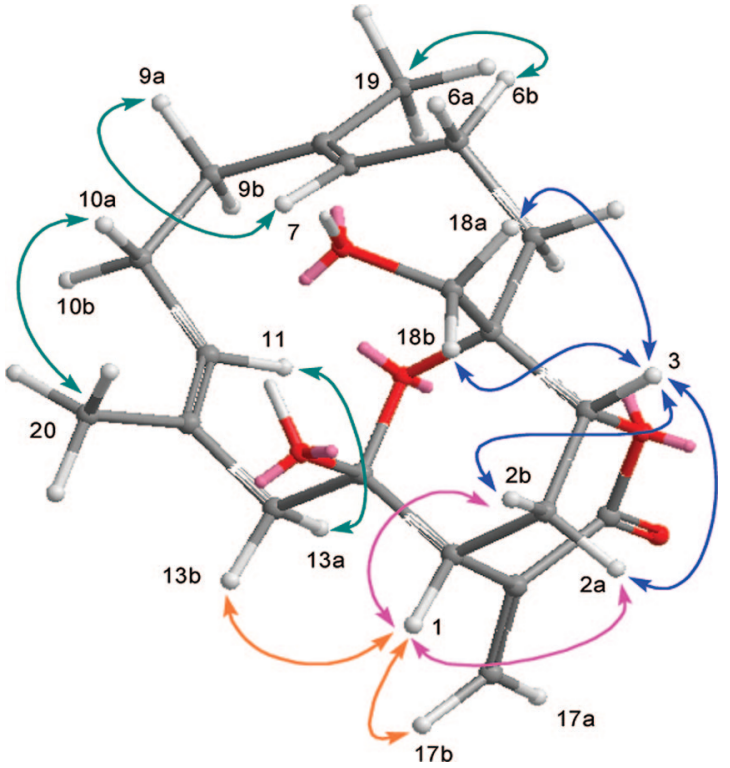

Figure 2. Key NOE correlations and computer-generated perspective model using MM2 force field calculations for $\mathbf{1}$.

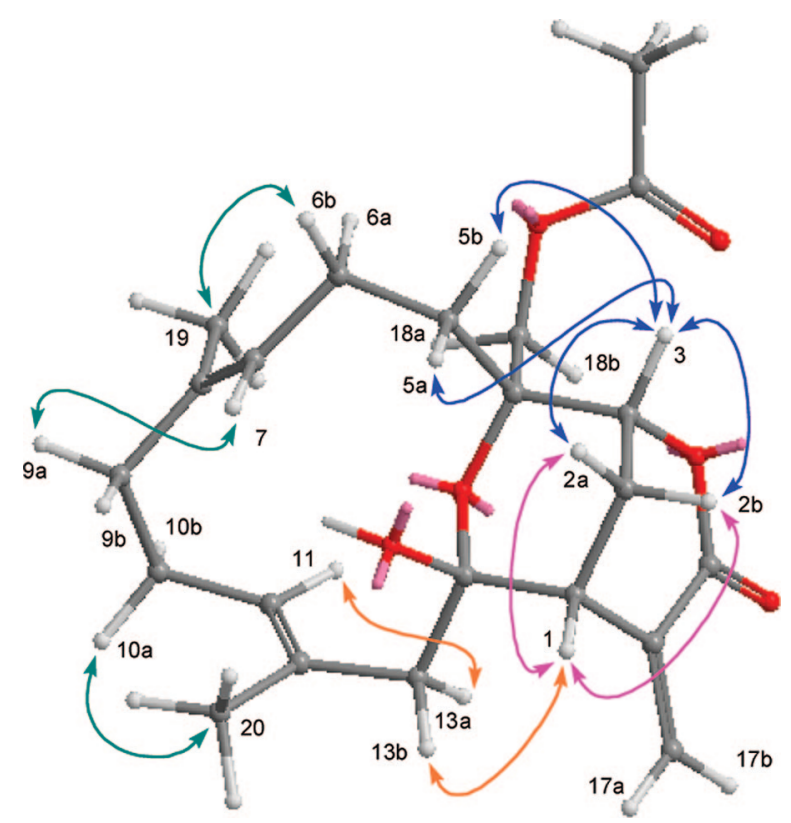

Figure 3. Key NOE correlations and computer-generated perspective model using MM2 force field calculations for 3.

was replaced by an 18-acetoxy $\left[\delta_{\mathrm{H}} 4.34\right.$ and $4.00(2 \mathrm{H}$, each d, $J=$ $12.0 \mathrm{~Hz})$ and $2.09(3 \mathrm{H}, \mathrm{s}) ; \delta_{\mathrm{C}} 67.3\left(\mathrm{CH}_{2}\right), 20.9\left(\mathrm{CH}_{3}\right)$, and 171.7 (qC)] in 1. HMBC correlation between $\mathrm{H}_{2}-18$ and $\mathrm{C}-21$ confirmed the placement of the acetoxy at $\mathrm{C}-18$. The relative configuration of $\mathbf{2}$ was determined through inspection of the NOESY spectrum as well as a computer-generated lower energy conformation using MM2 force field calculations. NOE analysis revealed that metabolite 2 possessed the same configurations at C-1, C-3, C-4, and C-14 as in 1. From the above observations, the structure of durumhemiketalolide B (2) was fully deduced as $\left(1 R^{*}, 3 R^{*}, 4 S^{*}, 14 S^{*}, 7 E, 11 E\right)$ 18-acetoxy-14-hydroxy-4,14-epoxycembra-7,11,15(17)-trien-16,3olide.

Durumhemiketalolide C (3) was found to possess the same molecular formula, $\mathrm{C}_{22} \mathrm{H}_{30} \mathrm{O}_{6}$, as that of $\mathbf{2}$ on the basis of the positive HRESIMS $\left(m / z 413.1942[\mathrm{M}+\mathrm{Na}]^{+}\right)$and NMR data (Tables 1 and 2). Comparison of the ${ }^{1} \mathrm{H}$ and ${ }^{13} \mathrm{C}$ NMR data of $\mathbf{3}$ with those of 2 showed that both metabolites possess similar structures. This 
(A)

iNOS

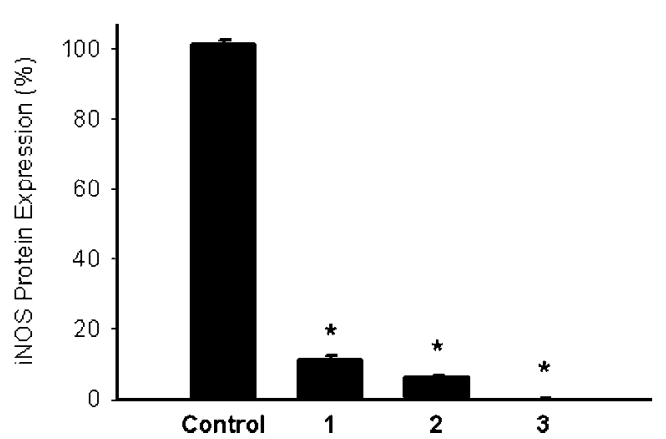

(B)

\section{$\operatorname{cox}-2$}

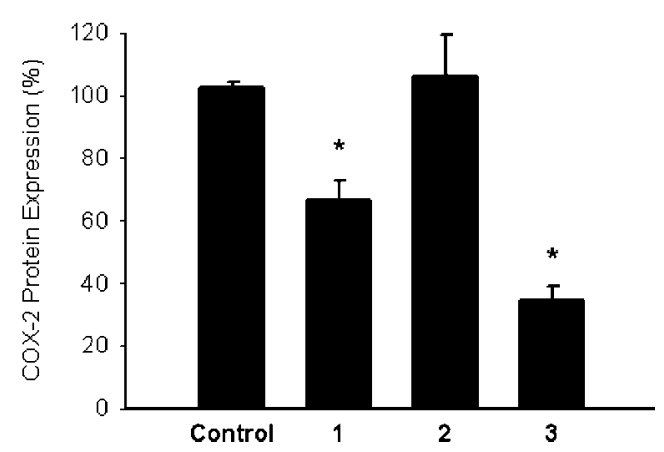

Figure 4. Effect of metabolites 1-3 at $10 \mu \mathrm{M}$ on the LPS-induced pro-inflammatory iNOS and on COX-2 protein expression of RAW 264.7 macrophage cells by immunoblot analysis. (A) Immunoblot of iNOS. (B) Immunoblot of COX-2. A and B values are mean \pm SEM $(n=5)$. The relative intensity of the LPS alone stimulated group was taken as $100 \%$. *Significantly different from LPS-stimulated (control) group $(* P<0.05)$.

was further supported by the planar structure established by 2D NMR analysis of 3 . However, it was found that the chemical shifts of $\mathrm{H}-3\left(\delta_{\mathrm{H}} 4.16\right)$ and $\mathrm{H}-5\left(\delta_{\mathrm{H}} 2.27\right.$ and 1.71$)$ in 3 were markedly different from those of 2 ( $\delta_{\mathrm{H}} 4.48,1.75$, and 1.66 , respectively). Further, since H-3 did not exhibit a NOE correlation with $\mathrm{H}_{2}-18$ (Figure 3), it was reasonable to conclude that the configuration of C-4 in metabolite $\mathbf{3}$ was opposite that in $\mathbf{2}$. This evidence suggested that durumhemiketalolide $\mathrm{C}(3)$ was $\left(1 R^{*}, 3 R^{*}, 4 R^{*}, 14 S^{*}, 7 E, 11 E\right)$ 14,18-dihydroxy-4,14-epoxycembra-7,11,15(17)-trien-16,3-olide.

Our previous study has reported that cembranolides possess iNOS (inducible nitric oxide synthetase) and COX-2 (cyclooxygenase-2) inhibition, ${ }^{9}$ which prompted us to evaluate the anti-inflammatory effect of these isolated metabolites. As shown in Figure 4, the in vitro anti-inflammatory activity of metabolites $\mathbf{1 - 3}$ was tested using LPS-stimulated cells. Stimulation of RAW 264.7 cells with LPS resulted in up-regulation of the pro-inflammatory iNOS and COX-2 proteins. Both metabolites $\mathbf{1}$ and $\mathbf{3}$ reduced the levels of iNOS to $11.0 \pm 1.3 \%$ and $0.0 \pm 0.0 \%$, respectively, and of COX-2 to 66.7 $\pm 6.4 \%$ and $34.7 \pm 4.2 \%$, respectively, in comparison with those of the control groups. Metabolite 2 reduced iNOS protein expression $(6.4 \pm 0.2 \%)$, but did not inhibit COX-2 protein expression. None of these isolated compounds affected $\beta$-actin protein expression at a $10 \mu \mathrm{M}$ concentration. Under the same experimental conditions, $10 \mu \mathrm{M}$ CAPE (caffeic acid phenylethyl ester) reduced the levels of iNOS and COX-2 proteins to $1.5 \pm 2.1 \%$ and $70.2 \pm 11.5 \%$, respectively, relative to the control cells stimulated with LPS.

Preliminary antibacterial activity assays revealed that none of these isolated metabolites exhibited any antibacterial activity against $S$. enteritidis at a concentration of $100 \mu \mathrm{g} / \mathrm{disk}$. The results for inhibition of HCMV endonuclease activity were all negative at a concentration of $1 \mathrm{mg} / \mathrm{mL}$.

The absolute configurations of these isolated metabolites remain to be determined because of the scarcity of material. It is worthwhile to mention that metabolites $\mathbf{1 - 3}$, possessing an $\alpha$-methylene- $\delta$ lactone ring cis-fused to a 14-membered ring with an unusual hemiketal tetrahydropyran moiety, are reported herein for the first time.

\section{Experimental Section}

General Experimental Procedures. Optical rotations were determined on a JASCO P1020 polarimeter. UV spectra were obtained on a Hitachi U-3210 spectrophotometer, and IR spectra were recorded on a JASCO FT/IR-4100 spectrophotometer. The NMR spectra were recorded on a Varian Unity INOVA 500 FT-NMR spectrometer at 500 $\mathrm{MHz}$ for ${ }^{1} \mathrm{H}$ and $125 \mathrm{MHz}$ for ${ }^{13} \mathrm{C}$. Chemical shifts are expressed in $\delta$ (ppm) referring to the solvent peaks $\delta_{\mathrm{H}} 7.27$ and $\delta_{\mathrm{C}} 77.0$ for $\mathrm{CDCl}_{3}$, respectively, and coupling constants are expressed in Hz. ESIMS were recorded by ESI FT-MS on a Bruker APEX II mass spectrometer. Silica gel 60 (Merck, 230-400 mesh) was used for column chromatography; precoated Si gel plates (Merck, Kieselgel $60 \mathrm{~F}_{254}, 0.25 \mathrm{~mm}$ ) were used for TLC analysis. $\mathrm{C}_{18}$ reversed-phase silica gel (230-400 mesh, Merck) was also used for column chromatography. High-performance liquid chromatography (HPLC) was performed on a Hitachi L-7420 UV detector L-7100 pump apparatus equipped with a Merck Hibar RP$18 \mathrm{e}$ column $(250 \times 10 \mathrm{~mm}, 5 \mu \mathrm{m})$.

Animal Material. The soft coral $L$. durum was collected by hand using scuba at the Dongsha Islands, Taiwan, in June 2007, at a depth of $7 \mathrm{~m}$, and was stored in a freezer for two weeks until extraction. This soft coral was identified by one of the authors (C.-F.D.). A voucher specimen (NSY-TS-13) was deposited in the Department of Marine Biotechnology and Resources, National Sun Yat-sen University.

Extraction and Isolation. The frozen soft coral $(1 \mathrm{~kg})$ was chopped into small pieces and extracted exhaustively by maceration with fresh acetone for $24 \mathrm{~h}$ at room temperature. The quantity of solvent used for each extraction $(2 \mathrm{~L})$ was at least three times the amount of the soft coral material used. The acetone extracts were filtered and concentrated under vacuum to yield a brownish oily residue, which was subsequently partitioned between EtOAc and $\mathrm{H}_{2} \mathrm{O}$. The resulting EtOAc-soluble residue $(20 \mathrm{~g})$ was subjected to column chromatography on silica gel using $n$-hexane with increasing amounts of EtOAc, and finally $100 \%$ $\mathrm{MeOH}$ for elution to furnish 30 fractions. Then, the ${ }^{1} \mathrm{H}$ NMR spectroscopic data were employed to detect the terpenoid-rich fractions. Fraction 19 (336 mg), which eluted with $n$-hexane/EtOAc (1:10), was separated by column chromatography on reversed-phase $\mathrm{C}_{18}$ gel column using $65 \% \mathrm{MeOH}$ in $\mathrm{H}_{2} \mathrm{O}, 70 \% \mathrm{MeOH}$ in $\mathrm{H}_{2} \mathrm{O}$, and $100 \% \mathrm{MeOH}$. Altogether, six subfractions were obtained, of which subfraction 5 (214 $\mathrm{mg}$ ) was further purified by reversed-phase HPLC using an isocratic solvent system of $70 \% \mathrm{MeOH}$ in $\mathrm{H}_{2} \mathrm{O}$ to allow the isolation of $\mathbf{1}$ (1.0 $\mathrm{mg}), 2(3 \mathrm{mg})$, and $\mathbf{3}(1 \mathrm{mg})$ in pure form.

Durumhemiketalolide A (1): colorless oil; $[\alpha]^{25}{ }_{\mathrm{D}}+140(c$ c 0.1 , $\left.\mathrm{CHCl}_{3}\right)$; UV (MeOH) $\lambda_{\max }(\log \epsilon) 217(3.65) \mathrm{nm}$; IR (KBr) $v_{\max } 3435$, 2920, 1716, 1276, 1044, $943 \mathrm{~cm}^{-1} ;{ }^{1} \mathrm{H}$ NMR and ${ }^{13} \mathrm{C}$ NMR data, see Tables 1 and 2; ESIMS $m / z 371[\mathrm{M}+\mathrm{Na}]^{+}$; HRESIMS $m / z 371.1835$ $[\mathrm{M}+\mathrm{Na}]^{+}$(calcd for $\mathrm{C}_{20} \mathrm{H}_{28} \mathrm{O}_{5} \mathrm{Na}, 371.1834$ ).

Durumhemiketalolide B (2): colorless oil; $[\alpha]^{25}+40$ (c 0.3 , $\left.\mathrm{CHCl}_{3}\right)$; UV (MeOH) $\lambda_{\max }(\log \epsilon) 214(3.76) \mathrm{nm}$; IR (KBr) $v_{\max } 3453$, 2925, 1744, 1721, 1275, 1239, 1044, $947 \mathrm{~cm}^{-1} ;{ }^{1} \mathrm{H}$ NMR and ${ }^{13} \mathrm{C}$ NMR data, see Tables 1 and 2; ESIMS $\mathrm{m} / \mathrm{z} 413$ [M $+\mathrm{Na}]^{+}$; HRESIMS $\mathrm{m} / \mathrm{z}$ $413.1943[\mathrm{M}+\mathrm{Na}]^{+}$(calcd for $\mathrm{C}_{22} \mathrm{H}_{30} \mathrm{O}_{6} \mathrm{Na}, 413.1940$ ).

Durumhemiketalolide C (3): colorless oil; $[\alpha]^{25}{ }_{\mathrm{D}}+130$ (c 0.1 , $\left.\mathrm{CHCl}_{3}\right)$; UV (MeOH) $\lambda_{\max }(\log \epsilon) 215(3.78) \mathrm{nm}$; IR (KBr) $v_{\max } 3452$, 2924, 1744, 1716, 1378, 1239, 1044, $943 \mathrm{~cm}^{-1} ;{ }^{1} \mathrm{H}$ NMR and ${ }^{13} \mathrm{C}$ NMR data, see Tables 1 and 2; ESIMS $\mathrm{m} / \mathrm{z} 413[\mathrm{M}+\mathrm{Na}]^{+}$; HRESIMS $\mathrm{m} / z$ $413.1942[\mathrm{M}+\mathrm{Na}]^{+}$(calcd for $\mathrm{C}_{22} \mathrm{H}_{30} \mathrm{O}_{6} \mathrm{Na}, 413.1940$ ).

Biological Assays. The in vitro anti-inflammatory activity assay, the HCM endonuclease assay, and the antibacterial assays were conducted as previously described. ${ }^{9}$

Acknowledgment. Financial support was provided by Ministry of Education (96C031703) and National Science Council of Taiwan (NSC96-2320-B-110-003-MY3) awarded to C.Y.D. 


\section{References and Notes}

(1) Blunt, J. W.; Copp, B. R.; Hu, W.-P.; Munro, M. H. G.; Northcote, P. T.; Prinsep, M. R. Nat. Prod. Rep. 2008, 25, 35-94.

(2) Higuchi, R.; Miyamoto, T.; Yamada, K.; Komori, T. Toxicon 1998, 36, 1703-1705.

(3) Matthee, G. F.; Konig, G. M.; Wright, A. D. J. Nat. Prod. 1998, 61, 237-240.

(4) Wang, S.-K.; Duh, C.-Y.; Wu, Y.-C.; Wang, Y.; Cheng, M.-C.; Soong, K.; Fang, L.-S. J. Nat. Prod. 1992, 55, 1430-1435.

(5) Coval, S. J.; Patton, R. W.; Petrin, J. M.; James, L.; Rothofsky, M. L.; Lin, S. L.; Patel, M.; Reed, J. K.; McPhil, A. T.; Bishop, W. R. Bioorg. Med. Chem. Lett. 1996, 6, 909-912.

(6) Duh, C.-Y.; Wang, S.-K.; Huang, B.-T.; Dai, C.-F. J. Nat. Prod. 2000, $63,884-885$.

(7) Bowdon, B. F.; Coll, J. C.; Heaton, A.; Konig, G.; Bruck, M. A.; Cramer, R. E.; Klein, D. M.; Scheuer, P. J. J. Nat. Prod. 1987, 50, $650-659$.
(8) Subrahmanyam, C.; Rao, C. V.; Anjaneyulu, V.; Satyanarayana, P.; Rao, P. V. S. Tetrahedron 1992, 48, 3111-3120.

(9) Cheng, S.-Y.; Wen, Z.-H.; Chiou, S.-F.; Wang, S.-K.; Hsu, C.-H.; Dai, C.-F.; Chiang, M. Y.; Duh, C.-Y. Tetrahedron 2008, 64, 96989704.

(10) Iwashima, M.; Matsumoto, Y.; Takenaka, Y.; Iguchi, K.; Yamori, T. J. Nat. Prod. 2002, 65, 1441-1446.

(11) Weinheimer, A. J.; Matson, J. A.; Hossain, M. B.; van der Helm, D. Tetrahedron Lett. 1977, 34, 2923-2926.

(12) Duh, C.-Y.; Wang, S.-W.; Tseng, H.-K.; Sheu, J.-H.; Chiang, M. Y. J. Nat. Prod. 1998, 61, 844-847.

(13) Duh, C.-Y.; Wang, S.-W.; Tseng, H.-K.; Sheu, J.-H. Tetrahedron Lett. 1998, 39, 7121-7122.

(14) Su, J.-H.; Ahmed, A.-F.; Sung, P.-J.; Chao, C.-H.; Kuo, Y.-H.; Sheu, J.-H. J. Nat. Prod. 2006, 69, 1134-1139.

NP800686K 